\title{
STUDENTS' ERROR IN USING PERSONAL PRONOUNS IN WRITING NARRATIVE TEXT AT TENTH GRADEOF SMAN 01 RAMBAH SAMO
}

\author{
${ }^{1}$ Wahyuni, ${ }^{2}$ Rivi Antoni \\ 1wahyni9@gmail.com, ${ }^{2}$ riviantoni@upp.ac.id, \\ English Study Program, Faculty of Teachers Training and \\ Education, University of Pasir Pangaraian
}

\begin{abstract}
The purpose of this research was to find out the types of students' error in using personal pronouns in writing narrative text. The indicators are: (1) Omission, (2) Addition, (3) Selection, (4) Ordering. By those indicators, the researcher would know the kinds of error that made by the students in using personal pronouns in writing narrative text. This was a qualitative descriptive study. The population was tenth grade students of SMAN 1 Rambah Samo. The samples were 29 student, that taken by using random sampling technique. The instrument was writing test. From the finding of the study, it can be seen in the high frequency error was made by students was error of selection with 75 errors, which means 60 $\%$ of error total. The next most error made by the students was error of ordering with 23 errors or $19 \%$. The students made 20 errors of error of omission or $16 \%$. They also made 6 errors of addition or $5 \%$. As a result, it can be concluded that the students still have problem in using personal pronouns in writing narrative text.
\end{abstract}

Keywords: Error Analysis, Personal Pronouns, Writing, Narrative Text

\section{INTRODUCTION}

In learning English, there are four skills that must be mastered by students: listening, speaking, reading andwriting. In the higher education and secondary school, writing is as a compulsory subject for students to learn (Antoni: 2016). Writing (as one of the four skills of listening, speaking, reading, and writing) has always formed parts of the syllabus in the teaching of English (Harmer, 2007:31). Eventhough, English has been taught to them but, the students still get difficult in mastering writing skill.

English writing is the most difficult skill to be mastered by students. Eventhough, It is caused by 
many aspect ruled in writing such as structure, vocabulary, punctuation, and spelling. Phuket and Normah (2015:99) say masteringEnglish writing skill is a very difficult task for the learners of English as a foreign language (EFL). They added that most of EFL students tend to make errors in writing. Language learners are always made errors as a natural step in the development of language skill. It means that students cannot avoid errors in learning process. Moreover, English is a foreign language for Indonesian students.

In writing activities there are many kinds of texts to learn, one of them is narrative text. Narrative is a story that should be related within stories and has function to entertain the reader which is happened in the past. This text is taught and learnt in first grade senior high school. In writing narrative text, grammar is one of the elements that important to be mastered by students.

The use of grammar is the most difficult thing for the students because it has many rules that should be considered by the students, especially the use of pronoun. In this case, the researcher only take personal pronouns to be analyze. Most of the students never consider the complexity of personal pronoun. In English, the usage of personal pronoun is different from Indonesia. Personal pronoun in English has many types and they also have different position and function It is tends students will be made some mistakes or even errors when they using English personal pronouns in writing narrative text.

This study aimed to investigate what types of error do students made in using personal pronouns in writing narrative text at tenth grade students of SMAN 1 Rambah Samo.

\section{REVIEW OF THE RELATED THEORIES}

In relation to the concept of error, errors are unavoidable in learning a foreign language (Amin;2017:68). Making mistakes or error is normal phenomena in process of learning.Error can be defined as the result of incomplete students' competence in learning. Students do not know if they make errors caused by the lack of students' knowledge. As stated by Corder (1974: 259) in Jabeen (2014:88),errors are the result of incomplete learning and linguistic incompetency of the learners and errors cannot be self-corrected.

There are several types of error in learning written language. According to Corder (1981:36) classifies errors into four different categories, there are: addition, omission, selection, and ordering. However, errors that are mostly made by the students should be identified, classified or described which called error analysis.

Brown (2000:218) says that error analysis is the study of learner's errors that can be observed, analyzed and classified to reveal something of the system operating within the learner, led to a surge of study of learner's errors. Donal (2015:102) states that mistakes or lapses are caused by stress, fatigue, 
boredom, emotion, or learners' slip of tongue and tend to be not systematic. Error analysis happen caused by students' unsuccessful in learning foreign language..

In discussion about narrative,Zumakhsin and Yulia (2013:44) state narrative is a text that is aimed to entertain, amuse, teach a lesson or moral, explain something or make a comment. There are many types of narrative text. According to Fakeye, Bosede and D.O (2016:273) generally, narrative texts could be categorized into the fictional narrative or imaginary, the non-fictional narrative, or combination of both. In writing narrative text personal pronouns is one of the elements that important to be mastered by students.

Personal pronoun in English has many types and they also have different position and function. Swick (2009:57) states the personal pronouns have a subjective form, an objective from, and a possessive form. For example as the first person in English used as a subject (I, you, we, they, she, he, it), object (me, you, us, them, her, him, it), possessive adjective (my..., your..., our..., their..., her..., his..., its...) and possessive pronoun (mine, yours, ours, theirs, hers, his, its). Contrary Indonesia personal pronouns consist of saya/aku, kamu/ anda, dia, mereka, kami/ kita and kalian. As we know that both as subject or object, they have the same forms and not change in any position in sentence.

\section{RESEARCH METHODOLOGY}

The research design used in this study was descriptive qualitative. According to Bogdan and Biklen (2007:5) qualitative research is to gain the data in the form of words or pictures rather than numbers. The population of this research was 196 students in the tenth grade of SMAN 1 Rambah Samo. Because, it was too large, the researcher only took $15 \%$ of the population as sample or 29 students by using random sampling technique. The instrument of this research used written test.

To analyze the data the researcher used theory by Corder. According to Corder (1974) in Ellis and Barkhuizen (2005:57), the steps to analyze the data are: collection of sample learner, identification of errors, description of errors, explanation of errors,and evaluation of errors.

\section{FINDING AND DISCUSSION}

\section{A. Findings and Discussion}

This research was to find out the students error in using personal pronouns in writing narrative text. After collecting and analyzing thedata, the researcher could present the following finding about types of erro, as in the followng. 
Table.1 The Result of Students' Errors in Using Personal Pronouns in Writing Narrative Text Based on Types of Erors

\begin{tabular}{|l|l|c|c|}
\hline No. & \multicolumn{1}{|c|}{ Types of Error } & Frequency & Percentage \\
\hline 1. & Omission & 20 Errors & $16 \%$ \\
\hline 2. & Addition & 6 Errors & $5 \%$ \\
\hline 3. & Selection & 75 Errors & $60 \%$ \\
\hline 4. & Ordering & 23 Errors & $19 \%$ \\
\hline \multicolumn{2}{|l|}{ Total } & 124 Errors & $100 \%$ \\
\hline
\end{tabular}

Based on the data on table 1 , it shows that the students made many errors in their writing. The first was error of omission, there were $16 \%$ error or 20 made by the students. The second error was error of addition, There were $5 \%$ or 6 errors error.

The third error was error of selection. There were 75 errors or $60 \%$ in selection. These were the most error students made in writing. It means, almost every student made error of selection in their writing. The fourth error was error of ordering. There were 23 errors or $19 \%$ errors in this type. Furthure, here are the descriptions of the error.

\section{a. Errors of Omission}

The total error of omission in using personal pronoun in writing narrative text made by students were 20 errors. This type of error was any form of the absence of an item that must appear in a sentence. This included:

\section{1) Omission of subject}

To write good sentences the writer must develop the subject, verb or tobe as ordinary verb in nominal sentence and complement. There were 2 errors of omitting subject. The fact was students still omit the subject of the sentence. Here are the examples of students' error.

Example:

One day the ... give invitation to people to come to his palace.

In the example above, the students did not write the subject of the sentence. In every sentence should have one subject. Thus, the reconstructed sentence should be:

One day the prince gave invitation to people to come to his palace.

\section{2) Omission of object}

In writing simple sentence, it should be constructed by subject + verb or tobe + object + complement. There were 2 errors of omission object pronouns. Here are the examples of students' error.

\section{Example:}

Then, Bandung Bondowoso fell in love with ... 
The sentence above is wrong because the students didi not write the object. In pronouns object divided into 7, they are (me, you, us, them, her, him, it). Thus, the reconstructed sentence should be: Then, Bandung Bondowoso fell in love with a girl.

\section{3) Omission of posessive adjective}

There were 16 errors omission possessive adjective. To write the owner of things or person correctly, it was very important. The fact, some of students still made error of omission in using possessive adjective. Such as:

... named sangkuriang.

In writing possessive adjective the pronouns should be followed by noun. The right pronoun for that sentence was his. Then, the suitable possessive adjective for man is his. It is to show the ownership of sangkuriang's name. The correct sentence was:

His named is Sangkuriang.

\section{b. Errors of Addition}

This type of error usually appears by adding any unnecessary morpheme in a sentence. Here are types and examples of addition errors found in students' writing.

\section{1) Addition of subject}

To write the sentence of the text, the writer must construct or arrange the sentence correctly. Moreover, most of the sentence use subject pronouns. It was found 1 error of addition subject. Here are the examples of students' error.But to arrive fish it disappear and on place to eat.

In the example above, the students put or add double subject pronouns is one sentence. They add the unnecessary letter that is not needed in the sentence. There was no needed to add fish. The correct sentence was:

but to arrive it disappear and on place to eat.

\section{2) Addition of object}

Every sentence should consist of some elements such as: subject, verb, object, complement, etc. There were 5 errors of addition object pronouns in students' writing. In a sentence should only appear one object. In fact, students still put more elements or morpheme of object in one sentence. Here are the examples of students' error:

She hammer hims in head

From the data shows there was the incorrect in using object personal pronouns. The students add $-\mathrm{s}$ in object pronouns (hims)which is it should be not appear and did not needed in that sentence. There was no pronouns of hims as function as object personal pronouns. The correct object pronouns for he is him without add - s. So, the right sentence was:

\section{She hammer him in head}

c. Selection

Selection refers to the problem of wrong selection of the certain forms. Thus, this errors are because the use of wrong form of the morpheme or 
structure. Here are types and examples of addition errors found in students' writing.

\section{1) Selection of subject}

There were 11 errors of selection in choosing subject that found in their writing. Some of the students still confused in applying subject personal pronouns properly. They choose the inappropriate subject for the sentence. The example of error selection subject is below.

her must promise dear no to raise origin nature.

The sentence was wrong because the students used her as the subject of the sentence. Her in personal pronouns was not used as subject but used as possessive adjective. This to show the ownership of something, not appropriate used as subject personal pronouns. The correct subject that should be written by the students is $h e$. Thus, the correct one should be:

he must promise dear no to raise origin nature

\section{2) Selection of object}

There were 23 errors in selecting object personal pronouns in the sentence. Some of the students still did not comprehend in using object pronouns in their writing. Here is the example of students' error in selection object.

He met Cinderella and he fall in love with hers

The error in that sentence is the use of hers as the object of the sentence. Hers in personal pronouns was not used as the object but used as the possessive pronouns. The possessive pronouns are not followed by noun. This pronoun can stand alone in the sentence. The correct object that should be chose in the sentence was her, without add $-\mathrm{s}$ in the end of the pronoun. The correct sentence is:

He met Cinderella and he fall in love with her".

3) Selection of possessive adjective Error of selection possessive adjective became the most error in selection type. there were 41 errors. To write the owner of things or person correctly it was very important to comprehend by the students. But, mostly they still could not distinguish to choose possessive adjective properly. The example of this kind of error is below.

A long time ago, live a young man, he name is Toba

The sentence is wrong because the student wrote $h e$ as the possessive adjective of name. Furthermore, there is no pronoun he act as possessive adjective.

d. Ordering

Ordering errors are where the elements presented are correct but wrongly sequenced. It means that ordering refers to the incorrect placement of words in a sentence or utterance. The word order errors found in the students' writing included ordering of:

1) Ordering of possessive adjective 
To write the owner of things or person correctly it was very important to comprehend by the students. The frequency that appear of error ordering in using possessive adjective were 23 errors. It means they often miss placement in using possessive adjective in their writing. Here is the example of students' error:

After night cinderella go to home with wasted shoes in house prince.

The sentence shows that the students did not order pronouns of possessive adjective correctly. house prince as function as possessive adjective of the data above was incorrect placements. The students should be write prince's house rather than house prince. So the correct sentence is:

After night cinderella go to home with wasted shoes in prince's house.

\section{Discussion}

After presenting the finding above, the researcher found allof existing types of errors, as mentioned byCorder (1981:36) in which, there are four types of errors: omission, addition, selection, and ordering. Concerning the data analysis and types of errors, it can be seen that the most kind of errors in students' writing narrative text in using personal pronouns were errors of selection.

This research also was in line with the research finding of (Dinnie: 2014 and Silvia: 2018), where those selection errors are found as the most frequent error that appeared.

Errors are found to be indicators of students' learning background. By knowing the errors, it can help teachers to provide suitable remedy in order to improve language acquisition and performance. Thus, it was better for the teacher to use this data to help the students in improving their writing, especially in using personal pronouns in writing narrative text.

\section{CONCLUSION AND SUGGESTION}

\section{A. Conclusion}

Finally this research could be concluded that the total error made by the students were 124 errors. The types of error that appear wereerror of omission were 20 errors or $16 \%$, error of addition 6 errors or $5 \%$, for error of selection there were 75 error or $60 \%$ error are found, and the fourth error was error of ordering. There were 23 errors or $19 \%$ of error ordering. It can be seen that the most error made by the students is "error of selection". In the other words, the tenth grade students of SMAN 1 Rambah Samo often made error in using personal pronouns in writing narrative text.

\section{B. Suggestion}

Based on the result of the research, the researcher would like to present some suggestions. Firstly, the teacher should give more easily understood explanation in order to 
make the students easier in learning personal pronouns.

Secondly, the students suggested to pay more attention to the teacher in teaching and learning process. Lastly, The next researcher suggested to find out the other relevant in using personal pronouns in writing narrative text.

\section{REFERENCES}

Amin, Aras Abdalkarim. (2017). The Frequency of Morpho-Syntactic Errors by Kurdish EFL Learners. IOSR Journal of Humanities and Social Science (IOSR-JHSS).Volume 22, Issue 3, Ver. V, March 2017.eISSN: 2279-0837, p-ISSN:22790845. www.iosjournals.org . Retrieved October $16^{\text {th }} 2018$.

Antoni, Rivi. 2016. Writing Task Activities in Developing Students' Writing Skill. Jurnal Ilmiah Edu Research Vol. 5 No. 1 Juni

2016. Retrieved June $25^{\text {th }} 2019$

Bogdan, R. C and Biklen, S. K. (2007). Qualitative Research For Education an Introduction To Theory and Methods. Boston: Pearson.

Brown, H. D. (2000). Principles of Language Learning and Teaching. New york: Longman
Corder, S. P. (1981). Error Analysis and Inter-language. London: Oxford University Press

Donal, Andri. (2015). Exploring Students' Errors in Constructing Sentences. Journal of English Education Vol. 1 No.2. ISSN: 2459-9719. 22 $2^{\text {nd }}$ January 2019.

Ellis, $R$ and Barkhizen, G. (2005). Analysis Learner Language. Oxford: Oxford University Press.

Fakeye. Bosede and D.O. (2016). Instruction in Text-Structures as A Determinant of Senior Secondary School Students' Achievement in English Narrative Text in Ido Local Goverment Area, Oyo State. International Journal of Arts and Humanities (IJAH) Bahir Dar-Ethiopia. Vol. 5 (2), S/No 17. ISSN: 2225-8590. Retrieved January $21^{\text {st }} 2019$.

Harmer, Jeremy. (2007). How to Teach Writing.

New York: Longman.

Phuket, P. R. N. And Normah, B. O. (2015).

Understanding EFL Students' Error in Writing. Journal of Education and Practice. Vol.6, No.32. ISSN 2222-1735 (Paper) ISSN 2222-288X (Online). www.iiste.org. Retrieved January $25^{\text {th }}$ 2019. 
Swick, Ed. (2009). Practice Make Perfect English Sentence Builder. New York: Mc Graw Hill

Zumakhsin and M, Yulia. (2013). Progress A Contextual Approach to Learning English An English Textbook for Senior High School. Jakarta: Ganeca 